\title{
研究会抄録
}

\section{第19回 東北小児喘息アレルギー研究会}

\author{
会長：遠藤 廣子 \\ 日時：平成 16 年 6 月 12 日（土） \\ 会場 : 仙台市
}

\section{一般演題}

\section{1. 気管支喘息児の肺機能（第1 報）日常生活の評価法}

\section{高野恵・岸幹二 \\ (公立藤田総合病院小児科)}

喘息治療の目的は，喘息児の日常生活が支障なく出 来ることにある.このため, 患者教育と同時に, 日常 生活を把握するための喘息日誌, PEFRなどが必要と なる．より客観的に喘息の状態を評価するには，スパ イロメーターが適している．今回の喘息児の肺機能測 定でスパイロメーターは被検者により測定值が左右さ れ，測定回数が多いほど信頼度が高いことが判明した。

\section{12 番染色体には複数の小児喘息感受性遺伝子が存} 在する

鎌田 文顕 ${ }^{1)}$ ・邵 晨 垛 ${ }^{1)}$ ・鈴木 洋一1) 松原 洋一 ${ }^{1)} \cdot$ 五利真由美 2$) \cdot$ 長谷川耕一2) 白川 太郎 ${ }^{3)} \cdot$ 遠藤 廣子 ${ }^{4)} \cdot$ 高柳 玲子 ${ }^{4)}$ 中澤 千冬4) ・森川 利夫5) - 森川 2き6) 宮林 重明 7 . 千葉 靖 8$)$ ・斎藤 誠一 9

(東北大学大学院遺伝病学分野 ${ }^{1)}$, 理化学研究所遺伝子多 型研究センター ${ }^{2)}$, 京都大学大学院健康要因学講座 ${ }^{32}$, 東北労災病院小児科 ${ }^{4)}$, 森川小児科医院 ${ }^{5)}, J R$ 仙台病院 小児科 ${ }^{6)}$ ，独立行政法人国立病院機構仙台医療センター 小坚科 ${ }^{77}$ ，仙台赤十字病院小児科 ${ }^{87}$, 船山病院小児科 9) 12 番染色体上の候補遺伝子について, 小児喘息との 相関を検討した結果，STAT6の exon 1 の GT repeat多 型，NOS1の intron 2 の GT repeat多型と小児喘息との 相関が示唆された.また, C3AR1の一塩基多型 1526G/A と最重症の小児喘息との相関が示唆された。連鎖を示 寸領域には未知の感受性遺伝子の存在する可能性があ り, 12 番染色体には複数の感受性遺伝子があると考え られる。

\section{3.マイコプラズマ肺炎を契機に症状悪化がみられた 気管支喘息 2 症例の検討}

岡田 昌彦・秋葉かおり・清水 行敏 （米沢市立病院小児科）

症例 1 は 13 歳女览，症例 2 は 8 歳女児。発熱と咳嗽 のため入院し, 臨床学的にマイコプラズマ肺炎 (MP) と 診断された。経過中に IgG（症例 $1 て ゙ 2260$, 症例 $2 て ゙$ $2692 \mathrm{mg} / \mathrm{dl}$ ) および $\operatorname{IgE}$ (症例 1 で 1400 , 症例 2 で $520 \mathrm{U} / \mathrm{ml}$ ) の高值がみられた．症例 2 では IL-4 が $50 \mathrm{pg} / \mathrm{ml}$, IL-6 が $28 \mathrm{pg} / \mathrm{ml}$ と上昇を呈した. MPによる喘息症状の悪化に はアレルギーおよび炎症反応の関与が示唆された.

4. 小児アレルギ一疾患の発症の予知に関する検討

$$
\begin{aligned}
& \text { 森川 みき1) ・ 川野 豊 }{ }^{2)} \text { ・渡邊 美砂 }{ }^{3)} \\
& \text { 大芝 晃洋 }{ }^{4)} \text { - 野間 剛(5) - 小田嶋 博 }{ }^{6)}
\end{aligned}
$$

(JR 仙台病院小児科 ${ }^{1)}$ ，横浜赤十字病院小児科 ${ }^{2)}$ ，東邦大

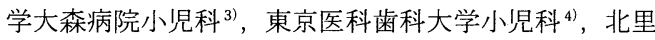
大学小児科 ${ }^{5)}$, 国立病院機構福岡病院小児科 ${ }^{61}$ )

アレルギーの発症と関連が深いと考えられる生後 1 年間の病歴を調査し，アレルギー疾患の発症因子につ いて検討した。

対象は各施設を受診した 1 歳児。家族の記載による 問診票から，妊娠分婏歴，栄養法および0歳から現在 までの罹患歷等と，児のアレルギー疾患の発症を検討 した．母のアレルギー歴，家族内のアレルギー疾患患 者数, 栄養法, 気道感染罹患の有無等が児のアレルギー 疾患の発症に影響を与えている可能性が示唆された.

\section{5. 小児気管支喘息患者の喘息症状の好発時間帯の調} 査

鶴田 靖（三沢市立三沢病院小监科） 小児気管支喘息の喘息症状の好発時間，症状，治療 前後の頻度を調查するために 7 ヶ $~ 14$ 歳までの喘息 患児 148 例の家族にアンケート調查を行った．喘息症 状は 19 時から 7 時にかけて多く，147例（99\%）がそ の時間帯に症状の既往があり，特に $21 \sim 22$ 時， $2 \sim 5$ 
時に好発し， 21 時と 4 時にピークが見られた。症状は 喘鳴, 咳嗽が多く, 頻度は過去の最も多い時期では週 1 日以上 147 例全例，現在は週 1 日以上 16 例（11\%） であった。

\section{6. 重症心身障害児・者病棟における気管支喘息の治} 療

黒沼忠由樹

(独立行政法人国立病院機構青森病院小坚科)

当院重症心身障害児・者病棟に入院の患児に合併し た気管支喘息の治療経過について報告した，症例は 2 歳 40 歳, 男児 2 , 女児 3 例で，全例抗痓攣剂を服用 していた.1例はベクロメサン゙ンの吸入と抗アレル ギー剂, テオフィリン製剤の内服, 1例は抗アレルギー 剤とテオフィリン製剤の内服，他はテオフィリン製剤 内服にて現在症状は軽快している．治療には薬の相互 作用を考慮したり，吸入も用手補助で行ったりなど治 療に難渋する例があった。

\section{7. 国立宮城病院の気管支喘息長期入院療法の 35 年}

堀川 雅浩

(独立行政法人国立病院機構宮城病院小児科)

当科の喘息患児の長期入院療法は平成 15 年で 35 周 年を向えた. 前半の 17 年と後半の 18 年と比較すると, 長期入院喘息患児は 583 名と 946 名, 平均入院期間は 1 年 11 力月と 6 力月であった。前半は外泊が少なく, 後半は毎週土日が外泊で, 外泊での発作が多かった。 再入院率を比較すると前半は $10 \%$, 後半は $20 \%$ で，入 院期間が短い後半が再入院率が高かった。

喘息と縁を切るには患児に長期に渡って発作を起こ さないようにすることが重要である.

\section{特別講演 I}

「喘息の呼吸理学療法」

宮川 哲夫 Ph D, RPT, PCET, RRT (昭和大学保健医療学部理学療法学科)

1997 年の NIH の喘息ガイドラインには急性発作時 の理学療法, 特にpercussion（軽打法）は気管支の攣 縮を引き起こし, 口すぼめ呼吸や腹式呼吸は呼吸穹迫
のコントロールには有効であるが，呼吸機能の改善は 困難であり，推奨していない。また，安定期の重症小 児喘息に対する排痰法は一秒量の低下は認めないが, 喘息症状の悪化や気胸を報告している。ささらに，重症 小児喘息発作では，粘液栓痰による肺葉虚脱を右上葉 に好発しやすい. Cochrane Review でも喘息の呼吸理 学療法の有用性は認めていない。しかし, 我々は喘息 発作に対する胸郭外胸部圧迫法による呼吸補助の有効 性を認めている．船橋市救命救急センターでは，救急 隊が搬送した喘息患者の 364 例に胸郭外胸部圧迫法を 実施し酸素飽和度の著明な改善を認め, 肋骨骨折や気 胸などの合併症の発症はなく良好な結果を得ており， 今後の普及を望む次第である。

\section{特別講演 II}

「ウィルス感染と気管支喘息発症との関わり」

河野 陽一

(千葉大学大学院医学研究院小児病態学)

小児気管支喘息発作の $80 \%$ 以上に気道ウィルス感 染が証明されており，喘息の病態に感染が重要な役割 を担うことが示唆されている。一方，最近乳児期の感 染がその後の気管支喘息の発症を抑制するという hygiene hypothesis も提唱され，感染と気管支喘息発症 との関わりは，完全には解明されていない，そこで， ウイルス感染が生体の免疫機構にどのような影響を与 えるのか, 重要な課題となっている。我々は, 疫学調 查などから気管支喘息の発症寄与因子として注目され ているRSウイルスによる細気管支炎において,アレル ギーに抑制的に働くTh1 サイトカインの産生が抑制さ れ，アレルギーに促進的な Th2 サイトカイン優位の環 境が形成されていることを明らかにした。 そこで, RS ウイルス感染に対する予防接種の確立も今後の気管支 喘息への重要な戦略と考えられる，本講演では，気管 支喘息発症と RSウイルス感染に焦点を当てて，RSウ イルスコンポーネントワクチンの可能性などを考えて みたい. 